\title{
THE INFLUENCE OF FINANCIAL PERFORMANCE AND CORPORATE GOVERNANCE MECHANISMS ON CAPITAL STRUCTURE
}

\author{
Emi Lusiana ${ }^{\bowtie}$, Ketut Sudarma
}

Management Department, Faculty of Economics, Universitas Negeri Semarang, Semarang, Indonesia

\section{Info Article}

History Article:

Received October 2018

Approved November 2018

Published December 2018

Keywords:

Capital Structure; Financial

Performance; Corporate

Governance.

\begin{abstract}
The research aims to determine whether asset structure, firm size, profitability, growth sales, board size and institutional ownership in the capital structure. The population of this research is all mining and mining service companies listed in Indonesia Stock Exchange period 2012-2016. The sample is 27 companies, so the data observation as much as 135 data. The data analysis technique used was linear regression analysis with the Random Effect Model approach. The result of data analysis showed that profitability and growth sales have a significant effect on capital structure. Profitability has significant negative affect and growth sales have a significant positive effect. The conclusion of this research showed that the capital structure on mining and mining service was influenced by profitability and growth sales, while asset structure, firm size, board size and institutional ownership did not have a significant effect. The writer suggests that the company should improve profitability by increasing the company's sales and stable sales growth in order to reduce the company's dependence on debt.

Abstrak

Penelitian ini bertujuan untuk mengetahui apakah variabel struktur aktiva, ukuran perusahaan, profitabilitas, ukuran dewan direksi dan kepemilikan institusional berpengaruh pada struktur modal. Populasi dalam penelitian ini adalah seluruh perusahaan pertambangan yang terdaftar di Bursa Efek Indonesia tahun 2012-2016. Sampel dalam penelitian ini ditentukan berdasarkan purposive sampling dengan jumlah sampel 27 perusahaan, sehingga data observasi sebesar 135 data. Analisis yang digunakan adalah analisis regresi linier berganda dengan pendekatan Random Effect Model. Hasil analisis data menunjukkan hanya variabel profitabilitas dan pertumbuhan penjualan yang berpengaruh pada struktur modal. Profitabilitas berpengaruh negatif signifikan dan pertumbuhan penjualan berpengaruh positif signifikan. Kesimpulannya struktur modal sektor pertambangan dipengaruhi profitabilitas dan pertumbuhan penjualan, sementara variabel struktur aktiva, ukuran perusahaan, ukuran dewan direksi dan kepemilikan institusional tidak memiliki pengaruh yang signifikan. Saran yang diberikan dalam penelitian ini yaitu perusahaan dapat meningkatkan profitabilitas dengan meningkatkan penjualan perusahaan dan pertumbuhan penjualan yang stabil dalam rangka mengurangi ketergantungan perusahaan pada hutang.
\end{abstract}

(C) 2018 Universitas Negeri Semarang

Correspondence Address:

L2 Building, 1st Floor, Faculty of Economics, Universitas Negeri Semarang

ISSN 2252-6552

Jalan Taman Siswa, Sekaran, Gunungpati, Semarang, 50229

E-mail: emilusiana4@gmail.com 


\section{INTRODUCTION}

The development of globalization causes significant tight competition (Priambodo et al., 2014). Each company is competing to increase innovation and productivity in order to appear on the market, to grow and maintain their life and certainly requires a lot of capital. One of the decisions faced by financial managers is associated with financing decisions or capital structure policy (Febriana \& Yulianto, 2017).

Riyanto (2011) stated that the capital structure is a permanent expenditure which reflects the balance between debt and equity. Company capital can be obtained from an internal and external source. Maytariana et al. (2013) stated capital structure is a combination of debt and equity in the financial structure of the company's long-term (long-term financial structure). Each company will set the proportion of debt (capital structure) with the needs and the financial situation faced (Haryanto, 2016). Determining how much capital is needed also a source of capital become an important task of the financial manager. In managing the fund, managers are required to seek low-cost funding and optimal composition, that is a capital structure that results in the lowest cost of capital (Sutrisno, 2016). Capital structure achieves optimal value when the composition of the debt and equity can increase the value of the company (Nugroho, 2014).

Capital structure affects the company's financial position (Nisasmara \& Musdholifah, 2016). Improperly funding decision will cause fixed costs in the form of high capital costs, which can result in low profitability and increase financial risks (Kartini \& Arianto, 2008). Financial risk is the risk as a result of the inability of the company to pay interest and installments of the loan in the economic situation worsening (Riyanto, 2008). Capital structure has to get the most attention by the company. The company's capital structure is influenced by many factors. Factors that affect the capital structure are the stability of sales, asset structure, financial leverage, the growth rate, profitability, tax, control, management attitudes, firm size and financial flexibility (Brigham \& Houston, 2006).

Various studies have been done, but still resulted in differences found in the study. Research conducted by Djabid (2009) shows the asset structure has a significant positive effect on the capital structure, but Serghiescu and Vaidean (2014) obtained the opposite result, that is a significant negative. Indrajaya et al. (2011) in his research indicates that firm size has a significant positive effect on the capital structure, but Chen (2004) obtained a significant negative result. Variables profitability that was studied by Nidar and Utomo (2017) shows profitability has a significant negative effect on the ca- pital structure, but research conducted by Watung et al. (2016) showed significant positive results.

Research conducted by Alvareza and Topowijono (2017) shows sales growth has a significant positive effect on the capital structure, but Nisak and Ardiansari (2016) obtained significant negative results. Board size examined by Sheikh and Wang (2012) shows significant positive results in affecting the capital structure, while Rahadian and Hadiprajitno (2014) obtained a negative effect but not significant. The last variable is the institutional ownership also still contain inconsistent results, among many researchers including research conducted by Artini and Diantini (2014) shows a significant negative effect of institutional ownership on capital structure, while Maftukhah (2013) in his research obtain significant positive results.

This study refers to the capital structure with a ratio of total debt to total equity or Debt to Equity Ratio latter called DER. The mining and mining service sector became the object of this study, mining and mining service sector still consider as an excellent in the capital markets, this results in the weight of the mining sector increased against the composite stock price index (CSPI). Growth in the mining and mining sector is not separated from the increased commodity data exports and imports, expected to contribute significantly Indonesian exports (www.kontan.co.id).

Mining and mining service companies also have a high level of risk as well. Risks faced by the mining and mining service company are the risk of fluctuations in commodity prices of mining products in world commodity markets. Also, the risks in exploration activities carried out by mining and mining service company (Indrajaya et al., 2011). The mining and mining service sector become an interesting sector to be observed since it tends to have an increasing average of DER and more than one that shows debt more than equity in the capital structure. The size of this ratio indicates a company's financial risk, where the greater DER then greater the financial risk faced by the company (Wardhani, 2015). Data on the average DER mining and mining service companies are as Figure 1.

\section{DER}

(in Percent)

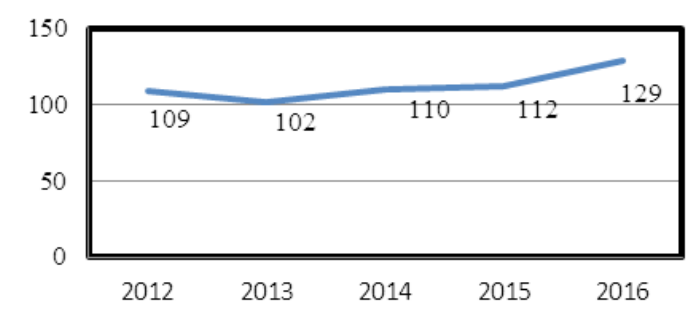

Figure 1. DER in 2012-2016 
Table 1. The average asset structure, firm size, profitability, sales growth, board size, institutional ownership and capital structure in 2012-2016.

\begin{tabular}{|c|c|c|c|c|c|c|}
\hline \multirow{2}{*}{ Variable } & \multirow{2}{*}{ Unit } & \multicolumn{5}{|c|}{ Mining and mining service sector } \\
\hline & & 2012 & 2013 & 2014 & 2015 & 2016 \\
\hline Asset Structure (-) & $\%$ & 25.00 & 31.00 & 32.00 & 35.00 & 28.00 \\
\hline Firm Size (-) & billion & 15.01 & 15.12 & 15.30 & 15.18 & 15.20 \\
\hline Profitability (-) & $\%$ & 5.36 & 3.66 & $(.33)$ & $(4.85)$ & .55 \\
\hline Sales Growth (-) & $\%$ & 13.60 & 18.00 & 138.00 & $(11.30)$ & 49.80 \\
\hline Board Size $(+)$ & person & 4.63 & 4.74 & 4.70 & 4.52 & 4.42 \\
\hline Institutional Ownership (-) & $\%$ & 38.00 & 40.00 & 39.00 & 39.00 & 39.00 \\
\hline Capital Structure (DER) & $\mathrm{X}$ & 1.09 & 1.02 & 1.10 & 1.12 & 1.29 \\
\hline
\end{tabular}

Based on Figure 1 shows that there is a problem of capital structure which always increased, only in 2013 which decreased. The increased in DER may benefit to reduced taxes, but also can increase the company's risk.

The average data on asset structure, firm size, profitability, sales growth, board size, institutional ownership and capital structure of the mining and mining service sector listed in Indonesia Stock Exchange 2012-2016 period can be seen in Table 1.

According to Table 1, the data phenomenon showed that the positive effect. This is not corresponding with the pecking order theory, companies that most of their capital is embedded in fixed assets, thus the company will make a priority to fulfill the needs of their permanent capital. In other words, the size of equity capital should be able to cover the number of fixed assets and other assets that are permanent (Hartoyo et al., 2014).

The firm size has a negative effect on the capital structure (Handoo \& Sharma, 2014) but based on the data phenomenon showed that the positive effect. This is not in accordance with the pecking order theory, where companies prefer internal to external funding. If the company faced increasing financial needs as a result of operations and sales growth, but it's retained earnings have been used, the company will use the funds from the debt and the issuance of new shares as the last option (Nuswandari, 2013).

Profitability has a negative effect on the capital structure (Nidar \& Utomo, 2017), but based on the data phenomenon showed that the positive effect. This does not fit with the pecking order theory, where the companies with high profitability tend to use a relatively small debt due to sufficient higher retained earnings in fi- nancing most of the funding needs (Zuliani \& Asyik, 2014). The sales growth has a negative effect on the capital structure (Seftianne \& Handayani, 2011) but based on the data phenomenon showed that the positive effect. This is not in accordance with the pecking order theory, where companies prefer internal to external funding. If the company faced increasing financial needs as a result of operations and sales growth, but it's retained earnings have been used, the company will use the funds from the debt and the issuance of new shares as the last option (Nuswandari, 2013).

The board size has a positive effect on the capital structure (Sheikh \& Wang, 2012) but based on the data phenomenon showed a negative effect. This is not appropriate with agency theory, where issuance debt is used as a governance mechanism to reduce conflicts of interest between agents and principals to reduce agency costs of free cash flow available for management (Jensen, 1986). The bigger board of directors applying high debt policy to enhance corporate value ( Sheikh \& Wang, 2012).

Institutional ownership has a negative effect on capital structure (Artini \& Diantini, 2014) but based on the data phenomenon showed a positive effect. This is not in accordance with agency theory where the existence of effective monitoring of institutional ownership led to the use of debt decreased, since the monitoring tool to decrease the distortion of the director. (Kohardinata \& Herdinata, 2013).

\section{Hypothesis Development}

The structure of assets (asset tangibility) is the ratio of fixed assets to total assets (Deesomsak et al., 2004). One of the assumptions of the pecking order theory is the existence of infor- 
mation asymmetry. When a company has a proportion greater tangible assets, assets appraisal becomes easier so that the problem of information asymmetry becomes lower (Hartoyo et al., 2014). Based on the pecking order theory, the asset structure has a negative effect on the capital structure. This indicates the greater company asset structure; there is a trend of companies using a relatively small debt. Companies that most of their capital is embedded in fixed assets, thus the company will make a priority to fulfill the needs of their capital permanent capital. In other words, the size of equity capital should be able to cover the number of fixed assets and other assets that are permanent (Hartoyo et al., 2014).

H1: Asset structure has a negative effect on the capital structure.

The firm size is one of the factors considered firm policy decision how much funding (capital structure) to meet the size or magnitude of the company's assets (Kartini \& Arianto, 2008). A big company certainly requires greater funds to support their operations, in addition to the large companies generally have greater sales level (Nuswandari, 2013). Based on the pecking order theory, companies prefer internal to external funding. If the company faced increasing financial needs as a result of operations and sales growth, but their retained earnings have been used, the company will use the funds from the debt and the issuance of new shares as the last option (Nuswandari, 2013). Based on the pecking order theory firm size has a negative effect on the capital structure. It shows that a large company used a relatively small debt. Large companies have a high risk of bankruptcy, so they prefer internal financing and cautious in using debt (Pithaloka, 2009).

H2: Firm size has a negative effect on the company's capital structure.

Profitability is the company's ability to earn income from their business activity (Maryanti, 2016). Based on the pecking order theory, the higher the profitability of the company, the higher the capital structure (Thausyah \& Suwitho, 2015). This is because companies that have high profitability tend to use a relatively small debt because of higher retained earnings that are sufficient to finance most of the funding needs (Zuliani \& Asyik, 2014). Moreover, managers prefer internal financing for their project, since it tends to lead an information asymmetry between managers and outside investors (Deesomsak et al., 2004). Furthermore, Deesomsak et al. (2004) stated that profitable companies prefer to not increase external equity to avoid potential dilution of ownership.

H3: Profitability has a negative effect on capital structure.

Sales growth is the company's ability to enhance the company's objectives in their attempt improving the financial performance of the company (Maryanti, 2016). Hardiningsih and Oktaviani (2012) stated the company's growth is a description of how the development efforts of the current period compared with the previous period, a company which is experiencing high growth means managed to increase the value of the company to generate profit or gain. Companies with a high growth rate will further maximize the use of resources that have retained earnings (Hardiningsih \& Oktaviani, 2012). Based on the pecking order theory, companies prefer internal to external funding. If the company faced increasing financial needs due to the growth in sales, but their retained earnings have been used, the company will use the funds from the debt and the issuance of new shares as the last option (Nuswandari, 2013).

$\mathrm{H} 4$ : Sales growth has a negative effect on the capital structure.

The board size showed the number of board of directors of the company (Abor \& Biekpe, 2007). According to the agency theory, there is a conflict of interest between agents and principle, the issuance of debt tends to be used as a governance mechanism to reduce conflicts of interest between agents and principals by reducing the agency costs of free cash flow available for management (Jensen, 1986). Jensen (1986) found that companies with larger board size have higher financial leverage than the smaller size of the board and it shows that companies with a large board size tend to use more debt financing than equity. Companies with a larger board of directors may utilize a network of directors who enable them to have better access to external financing (Detthamrong et al., 2017). The board of directors greater is applying high debt policy to enhance corporate value ( Sheikh \& Wang, 2012).

H5: Board size has a positive effect on the capital structure.

Institutional ownership variable indicates the concentration of shareholders outside the company owned by an institution or government 
agency or private (Djabid, 2009). Maftukhah (2013) states that institutional ownership generally acts as parties to monitor the company. They feared that the company's management is not able to manage the company well, it will negatively affect their stock where there is a large investment (Wirjawan, 2015). Suriana and Saripujiana (2015) believe that if the company uses a high debt to fund projects or the investments are a high risk that institutional shareholders may sell shares held thereby making managers more cautious in taking the decision to use debt to fund the company. Shareholding by a high institution (institutional ownership) will cause a greater control effort by the institutional ownership that can prevent distortion that will be done by the manager (Kohardinata \& Herdinata, 2013). Furthermore, Kohardinata and Herdinata (2013) declared effective monitoring of institutional ownership lead to the use of debt decreased due to the role of debt as a monitoring tool has been taken over by institutional ownership reduce agency cost of debt.

H6: Institutional ownership has a negative effect on the capital structure.

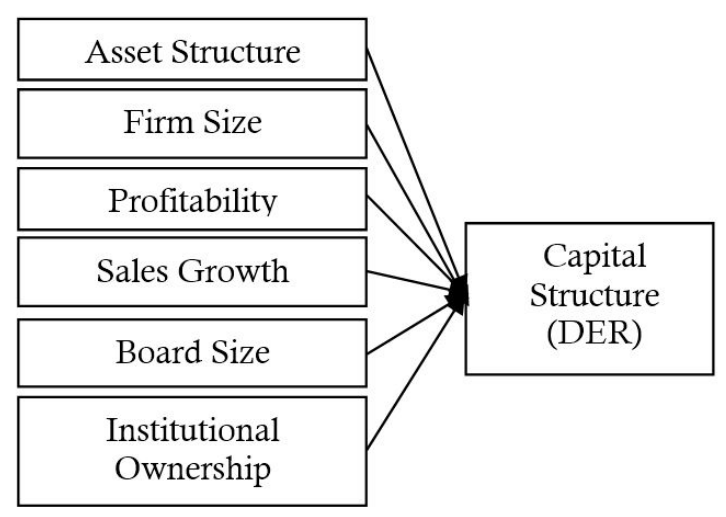

Figure 2. Framework of thinking

\section{METHOD}

In this study the type of research use science explanatory research which is the type of research conducted according to the type of coverage explanation or clarification kind of science that will be generated by research (Ferdinand, 2014).

The method used in the study is the documentation method which is collecting the data related to the asset structure, firm size, profitability, sales growth, board size, institutional ownership and capital structure. The approach used in this research is quantitative approach using secondary data, financial ratios derived from the Indonesian Stock Exchange and Indonesian Capital
Market Directory (ICMD) in the form of financial statements that mining companies listed on the Indonesia Stock Exchange 2012-2016 period.

In this study the data sources are obtained through the financial statement, an annual report published through the website Indonesian Stock Exchange also financial data processed by the Indonesian Capital Market Directory (ICMD).

The population in this study is the entire mining and mining service company listed on the Indonesia Stock Exchange year period 20122016. The researcher uses purposive sampling technique. The qualified company consists of 27 companies with a 5-year study period, so the observation data are 135 research data.

The data in this study using panel data is the dataset where the cross-sectional behavioral unit (e.g., individuals, companies, state) were observed over time (Ghozali \& Ratmono, 2013). Multiple regression analysis is used as the data analysis techniques. Before performing regression analysis with panel data Chow, Hausman and Langrange Multiplier test. Multiple linear regression equation in this study are:

$$
\begin{aligned}
\operatorname{DER}_{\text {it }}= & \beta_{1}+\beta_{2} \mathrm{AT}_{\text {it }}+\beta_{3} \mathrm{SIZE}_{\text {it }}+\beta_{4} \mathrm{PROF}_{\text {it }}+ \\
& \beta_{5} \mathrm{GROWTH}_{\mathrm{it}}+\beta_{6} \mathrm{BOARD}_{\mathrm{it}}+\beta_{7} \mathrm{INST}_{\mathrm{it}} \\
& +w_{\mathrm{it}}
\end{aligned}
$$

The variables in this study consist of dependent variables, those are capital structure and six independent variables are asset structure, firm size, profitability, asset growth, the board size and institutional ownership.

The capital structure is permanent expenditure which reflects the balance between longterm debt and equity (Riyanto, 2008). In this study, the capital structure is proxied by debt to equity (DER). Kasmir (2015) stated that debt to equity ratio is a ratio used to assess the debt for equity. This ratio is useful to know the number of funds provided the borrower (creditors) to the owner of the company. The formula used to find the debt to equity ratio is as follows:

$$
\text { DER }=\frac{\text { Total Liabilities }}{\text { Total Equity }}
$$

Firm size is how big or small the size of a company (Darmanto \& Ardiansari, 2017). In this study, the firm's size is proxied by the value of the natural logarithm of total assets. The formula used to calculate the size of the company is as follows (Serghiescu \& Văidean, 2014):

$$
\text { Size }=\operatorname{Ln}(\text { total asset })
$$


Table 2. Results Descriptive Statistic

\begin{tabular}{lccccccc}
\hline & DER & AT & SIZE & PROF & GROWTH & BOARD & INST \\
\hline Mean & 1.4582 & .2905 & 15.0950 & .0078 & 1.1719 & 4.6148 & .6500 \\
Median & .7900 & .2811 & 15.2610 & .0169 & -.0044 & 4.0000 & .6922 \\
Maximum & 14.8100 & .7641 & 18.2890 & .3001 & 106.8300 & 10.000 & .9700 \\
Minimum & .0100 & .0051 & 11.9090 & -.7213 & -.9593 & 2.0000 & .1000 \\
Std. Dev & 2.0649 & .1716 & 1.5390 & .1086 & 9.7616 & 1.7059 & .2227 \\
Observations & 135 & 135 & 135 & 135 & 135 & 135 & 135 \\
\hline
\end{tabular}

Kasmir (2015) stated that the profitability ratio is the ratio to assess the ability of the company to gain profit. In this study, the ratio used is Return on Assets (ROA). Kasmir (2015) stated Return on total assets is a ratio that shows the results (return) on the number of assets used in the company. ROA is also a measure of the effectiveness of management to manage their investments. The formula used is as follows:

Sales growth is the change in the increase or decrease in sales from year to year can be seen in the report companies (Maryanti, 2016). Weston and Copeland (2008) calculate sales growth with the following formula:

$$
\text { Growth }=\frac{\text { Sales }_{t}-\text { Sales }_{t-1}}{\text { Sales }_{t-1}}
$$

Horne and Machowicz (2005) the board of directors are the communicators between shareholders and managers, who potentially become the most effective instrument for corporate governance. Their responsibility is to oversee how the company run their business. In this study, board size is proxied by the number of boards of directors in the company. Abor and Biekpe (2007) calculate the size of the board of directors systematically as follows:

\section{Board Size $=$ Number of Board}

Djabid (2009) argues that institutional ownership variable indicates the concentration of shareholders outside the company which is owned by an institution or government agency or private. Institutional ownership is a stock company owned by the institution or institutions (Jannah \& Khoirudin, 2017).
In this research, institutional ownership is proxied by the percentage of the number of shares held by institutions. Artini and Diantini (2014) mathematically stated that institutional ownership could be formulated as follows:

$$
I N S T=\frac{\text { Stock owned by institution }(\%)}{\text { Shares outstanding }}
$$

\section{RESULT AND DISCUSSION}

\section{Descriptive statistics}

The number of observations (sample size $\mathrm{x}$ period) in this study is $135(27 \times 5)$ observation. Descriptive statistical results are presented in Table 2. DER minimum value is 0.01 and the maximum value is 4.84 , the average value (mean) is 1.4582 with a standard deviation by 2.065 . The average value (mean) less than the standard deviation is $1.458<2.065$, demonstrating the spread of the data is less good.

AT the minimum value of 0,005 and The maximum value of 0.764 , the average value (mean) of 0.290 with a standard deviation of 0.172 . The average value (mean) greater than the standard deviation is $0.290>0.172$, demonstrating the spread of good data.

The minimum SIZE value is 11.91 and the maximum value is 18.289 , the average value (mean) is 15.095 with a standard deviation by 1.539. The average value (mean) greater than the standard deviation is $15.095>1.539$, it indicates a good data deviation.

The PROF minimum value is -0.721 and the maximum value is 0.300 , the average value (mean) is 0,008 with a standard deviation by 0.108 . The average value (mean) is less than the standard deviation of $0.008<0.108$, demonstrating the spread of the data is not good enough.

GROWTH minimum value is -0.959 and the maximum value is 106.83 , the value of the average (mean) is 1,172 with a standard devia- 
tion by 9.798 . The average value (mean) is less than the standard deviation of $1.172<9.798$, demonstrating the spread of the data is not good enough.

The BOARD minimum value is 2 and the maximum value is 10 , the average value (mean) is 4,615 with the standard deviation by 1.706 . The average value (mean) greater than the standard deviation is $4.615>1.706$, demonstrating the spread of good data.

The minimum INST value is 0.100 and the maximum value is 0.97 , the average value (mean) is 0.65 with the standard deviation by 0.223 . The average value (mean) is greater than the standard deviation of $0.65>0.223$ this indicates a good data deviation.

Based on the Chow, Hausman and Langrange multiplier test, regression model showed that the more suitable model is a random effect model. The following results display chow, Hausman and Langrange multiplier test:

Table 3. Chow Test result

\begin{tabular}{lccc}
\hline \multicolumn{1}{c}{ Effects Test } & Statistic & d.f & Prob. \\
\hline Cross-section F & 19.660902 & $(26,102)$ & .0000 \\
$\begin{array}{l}\text { Cross-section } \\
\text { Chi-square }\end{array}$ & 242.148334 & 26 & .0000 \\
\hline
\end{tabular}

Value Cross-section Chi-square $<\alpha$ with a probability value $0.0000<0.05$, so $\mathrm{H} 0$ is rejected. It is taken for granted that among models of Pooled OLS or Common Effect and Effect and Fixed Effect, the best model to be used as a panel data regression model is Fixed Effect.

Table 4. Hausman test result

\begin{tabular}{lccc}
\hline Test Summary & $\begin{array}{c}\text { Chi-Sq. } \\
\text { Statistic }\end{array}$ & $\begin{array}{c}\text { Chi-Sq. } \\
\text { d.f }\end{array}$ & Prob. \\
\hline $\begin{array}{l}\text { Cross-section } \\
\text { random }\end{array}$ & 5.544980 & 6 & .8634 \\
\hline
\end{tabular}

Value Cross-section random $>\alpha$ with a probability value $0.8634>0.05$, so $\mathrm{H}_{0}$ is accepted. This may be implied that among model of the Fixed Effects and Random Effects, the best model that can be used as a panel data regression model is Random Effect.

Table 5. Langrange Multiplier test result

\begin{tabular}{|c|c|c|c|}
\hline & Cross-section & Test Hypo time & Both \\
\hline $\begin{array}{l}\text { Breusch- } \\
\text { Pagan }\end{array}$ & $\begin{array}{c}163.0625 \\
(.0000)\end{array}$ & $\begin{array}{c}1.449050 \\
(.2287)\end{array}$ & $\begin{array}{c}164.5115 \\
(.0000)\end{array}$ \\
\hline
\end{tabular}

Probability Cross-section Breusch-Pagan $<\alpha$ with the value $0.0000<0.05$. This may be implied that among the random effect models and a common effect, the best model to be used as the panel data regression model is the random effect.

\section{Classic Assumption Test Normality Test}

Table 6. Normality Test Results

\begin{tabular}{lc}
\hline Jarque-Bera & 3.455554 \\
\hline Probability & .177679 \\
\hline
\end{tabular}

Based on the results of the Jarque-Bera normality test in Table 6 , it can be seen that the Jarque-Bera value smaller than the value of the table Chi-Square $(3.455554<9.4888)$ and the probability is greater than the sig. $\alpha(0.177679>$ 0.05) means that $\mathrm{H}_{0}$ is accepted and $\mathrm{H}_{\mathrm{a}}$ rejected, which means that the residuals are normally distributed

\section{Multicollinearity Test}

Based on the Table 7, multicollinearity test results with correlation matrix in Table 7, it can be seen that there is no a large enough coeffi-

Table 7. Multicollinearity Test Result

\begin{tabular}{lllllll}
\hline & AT & SIZE & PROF & GROWTH & BOARD & INST \\
\hline AT & 1.0000 & 0.3017 & 0.1208 & -0.0993 & -0.0447 & -0.0459 \\
SIZE & 0.3017 & 1.0000 & 0.3137 & 0.0329 & 0.6110 & 0.1317 \\
PROF & 0.1208 & 0.3137 & 1.0000 & 0.1158 & 0.2792 & 0.1191 \\
GROWTH & -0.099 & 0.0329 & 0.1158 & 1.0000 & 0.0442 & 0.1335 \\
BOARD & -0.044 & 0.6110 & 0.2792 & 0.0442 & 1.0000 & -0.0338 \\
INST & -0.045 & 0.1317 & 0.119110 & 0.133521 & -0.0338 & 1.0000 \\
\hline
\end{tabular}


cient, even all the correlation coefficient between independent variables still under the condition of multicollinearity which is 0.80 , so it does not present multicollinearity.

\section{Heteroscedasticity Test}

Table 8. Heteroscedasticity Test Result

\begin{tabular}{lc}
\hline \multicolumn{1}{c}{ Variable } & Probability \\
\hline $\mathrm{C}$ & .9972 \\
Asset Structure & .0920 \\
Company Size & .0966 \\
Profitability & .0753 \\
Sales Growth & .0803 \\
Board Size & .0515 \\
Institutional Ownership & .6201 \\
\hline
\end{tabular}

According to the Table 8 , the test results obtained by Glejser heteroscedasticity test showed that probability value of asset structure, company size, probability, sales growth board size, institutional ownership is greater than 0.05 , it means that there is no heteroscedasticity in the model.

Table 10. Random Effect Model Test Result

\section{Autocorrelation test}

Table 9. Autocorrelation Test Result (DurbinWatson Test)

\begin{tabular}{lc}
\hline \multicolumn{2}{c}{ Weighted Statistics } \\
\hline Durbin-Watson stat & 2.042290 \\
\hline
\end{tabular}

According to the Table 9, the obtained Durbin-Watson value is 2.042290 , so it is greater than the upper limit $(\mathrm{dU}=1.8035)$ and less than 4-dU $(4-1.8035=2.1965)$, so it can be concluded that there is no autocorrelation.

Based on Table 10, the Analysis techniques in this study is analysis of multiple regression using random effect with the following equation:

$$
\begin{aligned}
\text { DER }= & -0.049245-0.146933 \mathrm{AT}+0.008999 \mathrm{SIZE} \\
& -0.791992 \mathrm{PROF}+0.023271 \mathrm{GROWTH} \\
& +0.001965 \text { BOARD }-0.000851 \mathrm{INST}+ \\
& \text { Wit }
\end{aligned}
$$

Based on Table 11, it can be seen that the value of intercept (average) is $-0,049245$. The results of individual intercept (company) are presented in Table 11. The individual intercept will be compared with average intercept.

\begin{tabular}{lllll}
\hline Variable & Coefficient & Std. Error & t-Statistic & Prob. \\
\hline C & -0.049245 & 0.275826 & -0.178536 & 0.4294 \\
AT & -0.146933 & 0.161540 & -0.909575 & 0.1831 \\
SIZE & 0.008999 & 0.022562 & 0.398858 & 0.3456 \\
PROF & -0.791992 & 0.156471 & -5.061577 & 0.0000 \\
GROWTH & 0.023271 & 0.004433 & 5.249264 & 0.0000 \\
BOARD & 0.001965 & 0.020292 & 0.096830 & 0.4615 \\
INST & -0.000851 & 0.152372 & -0.138695 & 0.3500 \\
\hline
\end{tabular}

Table 11. Random Effect Model (Firm Effect)

\begin{tabular}{llllll}
\hline No & Firm & Effect & No & Firm & Effect \\
\hline 1. & ADRO & -0.067486 & 12. & HRUM & -0.056862 \\
2. & ANTM & -0.006512 & 13. & INCO & -0.019553 \\
3. & ARII & 0.079816 & 14. & KKGI & -0.019317 \\
4. & ARTI & -0.034372 & 15. & MITI & 0.052707 \\
5. & ATPK & 0.103578 & 16. & MYOH & -0.066048 \\
6. & CITA & 0.061841 & 17. & PKPK & -0.029535 \\
7. & CKRA & -0.123535 & 18. & PTBA & 0.080371 \\
8. & CTTH & 0.000352 & 19. & PTRO & -0.007082 \\
9. & DEWA & 0.001290 & 20. & SMMT & 0.043180 \\
10. & ELSA & -0.058664 & 21. & SMRU & 0.017326 \\
11. & GEMS & 0.000750 & 22. & TINS & 0.047752 \\
\hline
\end{tabular}


ADRO has a lower intercept by -0.067486 from a average intercept -0.049245 , then the actual intercept of ADRO is $-0.11673(-0.067486$ -0.049245 ). ANTM is -0.055757 , ARII is 0.03057 , ARTI is -0.083617 , ATPK is 0.054333 , CITA is 0.012596 , CKRA is -0.17278 , CTTH is -0.048893 , DEWA is -0.047955 , ELSA is -0.107909 , GEMS is -0.048495 , HRUM is -0.106107 , INCO is -0.068798 , KKGI is -0.068562 , MITI is 0.003462 , $\mathrm{MYOH}$ is -0.115293 , PKPK is -0.07878 , PTBA is 0.031126 , PTRO is -0.056327 , SMMT is -0.006065 , SMRU is -0.031919 and the last is TINS by -0.001493 .

\section{F Statistic Test}

Table 12. F Statistic Test Result

\begin{tabular}{lr}
\hline \multicolumn{2}{c}{ Weighted Statistics } \\
\hline F-Statistic & 32.623750 \\
Prob(F-Statistic) & .000000 \\
\hline
\end{tabular}

Based on the results of Table 12, The Probability (F-statistic) value 0.000000 , it can be concluded that the asset structure, company size, profitability, sales growth, the size of the board of directors and institutional ownership simultaneously affect the capital structure. Thus $\mathrm{H}_{\mathrm{a}}$ is accepted.

\section{The coefficient of Determination Test}

Table 13. The coefficient of Determination Test Result

\begin{tabular}{lc}
\hline \multicolumn{2}{c}{ Weighted Statistics } \\
\hline R-squared & .767963 \\
Adjusted R-squared & .744423 \\
\hline
\end{tabular}

In Table 13, it can be seen that the value of Adjusted R Square is 0.744423 or by $74.44 \%$, it means that the asset structure, firm size, pro- fitability, sales growth, the size of the board of directors and institutional ownership can explain $74.44 \%$ of the capital structure, while the remaining $25,66 \%$ is explained by other variables outside the model. The coefficient of determination is high enough; it means the ability of independent variables in explaining the dependent variable is large enough.

\section{Hypothesis Testing (T-test)}

Based on Table 14, the results of hypothesis testing (t-test) is as follows:

Based on the results of test calculations in Table 12, the partial asset structure variables $t$ value is -0.909575 and significance value is 0.1831 , it indicates that there is no significant negative effect between asset structure variables on capital structure, so $\mathrm{H}_{\mathrm{a} 1}$ rejected.

Variable firm size obtained $t$ value by 0.398858 and a significance value by 0.3456 , it shows that there is positive but not significant influence between variable sized companies on capital structure, so $\mathrm{H}_{\mathrm{a} 2}$ rejected.

Profitability variable obtained $t$ value by -5.061577 and the significance value by 0.0000 , it indicates that there is a significant negative effect on the profitability of variable capital structure, so $\mathrm{H}_{\mathrm{a3}}$ accepted.

Sales growth variables obtained $t$ value by 5.249264 and the significance value by 0.0000 , it indicates that there is a significant positive influence between the variables of sales growth in the capital structure, so $\mathrm{H}_{\mathrm{a} 4}$ rejected.

Variable board size obtained $t$ value by 0.096830 and a significance value by 0.4615 , which indicates that there is no significant positive effect between the variable board size on the capital structure, so $\mathrm{H}_{\mathrm{a} 5}$ rejected.

Institutional ownership variable obtained $\mathrm{t}$ value by -0.138695 and significance value by 0.3500 , it indicates that there is no negative effect significant between institutional ownership variables on capital structure, so $\mathrm{H}_{\mathrm{a} 6}$ rejected.

Table 14. T-Test Result

\begin{tabular}{lcccc}
\hline \multicolumn{1}{c}{ Variable } & Coefficient & Std. Error & t-Statistic & Prob. \\
\hline C & -.049245 & .275826 & -.178536 & .4294 \\
AT & -.146933 & .161540 & -.909575 & .1831 \\
SIZE & .008999 & .022562 & .398858 & .3456 \\
PROF & -.791992 & .156471 & -5.061577 & .0000 \\
GROWTH & .023271 & .004433 & 5.249264 & .0000 \\
BOARD & .001965 & .020292 & .096830 & .4615 \\
INST & -.000851 & .152372 & -.138695 & .3500 \\
\hline
\end{tabular}




\section{Assets Structure Influence on Capital Struc- ture}

Hypothesis test results show the asset structure has a significant negative effect on the capital structure. The negative effect shows that when the asset structure of the company increased, the company's capital structure will decrease and it applies vice versa. Not significant results indicate that the asset structure is not very influential in determining the capital structure on mining companies listed on the Indonesia Stock Exchange 2012-2016 period. These results are inconsistent with the hypothesis that states the asset structure significant negative effect on the capital structure.

These results indicate when the mining and mining service sector has a greater tangible assets proportion, assets appraisal becomes easier so that the problem of information asymmetry becomes lower and the use of debt would be lower. Hartoyo et al. (2014) states it is caused by the company's majority shareholding embedded in fixed assets, so they will give priority to fulfill the needs of capital from the permanent capital. In other words, the amount of equity capital should be at least be able to cover the number of fixed assets and other assets that are permanent. The results were not significant due to the problem of not too dominant information asymmetry in the mining and mining service sector.

Companies that have high asset structure tend to have large fixed assets; big fixed assets could help companies meet their capital requirements, so it only requires less addition of funds, in this case, the company will reduce the amount of funding through debt because only as a supplement. The results of this study are consistent with the pecking order theory where the company would be likely to use internal fund first since the internal resources have a smaller risk than external funding that has a risk in capital cost and company other costs.

The results of this study support the study from Ridloah (2010), Indriani and Widyarti (2013), Zuliani and Asyik (2014), Hartoyo et al. (2014), Wirjawan (2015), Thausyah and Suwitho (2015) and Dewi and Sudhiarta (2017) who states that the structure of assets has a negative effect but not significant on the capital structure.

\section{The influence of firm size on Capital Structure}

Hypothesis test results indicate the size of the company has a positive effect but not significant in the capital structure. Positive effect indicates that a larger company need greater funds that would increase funding through debt and it applies vice versa. Not significant results indicate that firm size is not too influential in determining the capital structure on mining companies listed on the Indonesia Stock Exchange 2012-2016 period. These results are inconsistent with the hypothesis that the size of the company's significant negative effect on the capital structure.

A large company requires large capital to maintain and develop their business. The need for large funding causes a large company to have a stronger need of bigger debt than a smaller company who need a lesser amount of debt. Moreover, a large company usually have a greater profit on operations performed. Thus the chance of the company to have retained earnings will be greater. However, this result does not correspond with the pecking order theory that states the company will use internal funds to meet the capital needs of the company when internal funds are insufficient, the company will switch on external funds. Priority mechanisms of external funding are through the issuance of debt (Yulianto et al., 2015).

These results indicate that the mining company's retained earnings are insufficient to meet the funding requirements, thus alternate their financing using debt as an option after retained earnings. The larger company will increase the use of debt due to insufficient retained earnings.

Chen (2004) stated that a positive relationship between firm size and capital structure because large firms have better access to capital markets since they already have a reputation and attractiveness advantage in the secondary market. Therefore, the high needs of the big fund and the company a good reputation will lead to the greater company's debt. However, the creditors not only consider the size of the company but also consider to other factors such as the company's prospects, assurance, management attitudes and so on, this is what causes the size of the company's effect is not significant.

These results support the research conducted by Lestari (2015), Wikartika and Fitriyah (2017), Nidar and Utomo (2017) and Sahabuddin (2017) which states that the size of the company has a positive effect but not significant in the capital structure.

\section{The influence of profitability on Capital Struc- ture}

Hypothesis test results show a significant negative effect on the profitability of the capital structure. A negative effect indicates that greater profitability leads the company to prefer using internal funds available in advance to meet the 
funding needs, thereby reducing the use of funds through debt. The results showed that the profitability significantly influential in determining the capital structure on mining companies listed on the Indonesia Stock Exchange 2012-2016 period. This is consistent with the proposed hypothesis. The greater the profitability of the company, the lower the funding through debt.

Companies with a high rate of return will use a relatively small debt. These results are consistent with the pecking order theory where companies prefer using internal funding before deciding to use external financing. Profitable companies have a lot of funds available in the form of retained earnings, the fastest source of financing, easiest and have a lower risk compared to the issuance of equity and debt. Retained earnings can be used for investments, thereby lower the use of debt, when of low profitability of the company, they will use high debt due to insufficient internal funds to fulfill their funds.

These results are supported by the results of Chen (2004), Indahningrum and Handayani (2009), Indriani and Widyarti (2013), Maftukhah (2013), Priambodo et al. (2014), Handoo and Sharma (2014), as well as Wardhani (2015) who state that profitability has a significant negative effect on the capital structure.

\section{The influence of Sales Growth on Capital Structure}

Hypothesis test results showed that significant sales growth has a positive effect on the capital structure. Positive effect indicates that the greater the sales growth, the company will require more funds. The results showed that the growth of sales significantly influential in determining the capital structure on mining companies listed on the Indonesia Stock Exchange 2012-2016 period. These results are inconsistent with the hypothesis that states sales growth significant negative effect on the capital structure.

These results demonstrate the greater sales growth, the greater the company's debt to fund such growth because retained earnings are not sufficient funds. Nidar and Utomo (2017) said that the companies with a high growth would require greater funding to acquire more assets and finance their project, so they will look for other sources of funding, especially through debt. This is not in accordance with the pecking order theory where the company would prefer using internal funding first, but when internal funds are insufficient, they will look for financing through external funds. Developing a company requires more funds to increase growth, so retained ear- nings are not the only source to fund their project, but also, they will use external funds. Sales growth is also a good signal since the company is able to generate increased sales; this will be one of the considerations for the creditors to lend the companies.

These results are supported by the results of research conducted by Chen (2004), Nugroho (2014), Naibaho and Azizah (2015), Maryanti (2016), Nidar and Utomo (2017) which states that sales growth has a positive significant effect on the capital structure.

\section{The influence of Board Size on Capital Struc- ture}

Hypothesis test results indicate board size has a positive effect but not significant in influencing the capital structure. Positive effect indicates that the greater the board size, the company prefers external funding. The results indicate that the board size has no significant effect on the larger amount of debt for mining and mining service companies listed on the Indonesia Stock Exchange 2012-2016. The findings are not consistent with the hypothesis that states the size of the board of directors of a significant positive effect on the capital structure.

In accordance with the theory of agency where issuance debt is used as a governance mechanism to reduce conflicts of interest between agents and principals in order to reduce agency costs of the free cash flow of the company. Companies with a larger board size typically have higher debt compared with the smaller size of the board, since it allows them to have access and better connections with creditors, so that external financing through will be more dominant than the internal funding.

Not significant results show that the size of the board of directors does not guarantee the debt is increasing, it could happen since the size of the board only describe the number of members, but does not explain the performance of the directors who are active in the strategic decisions for the company. Bulan and Yuyetta (2014) stated that size of the board is not a major determinant of effectiveness in implementing the corporate governance at the company in determining the strategic decisions, including determine the capital structure and often act in the specific interests and ignoring the interests of other shareholders (Yulianto et al., 2014)

These results are supported by research conducted by Hamzah and Suparjan (2009), Abor and Biekpe (2007), Bulan and Yuyetta (2014), Detthamrong et al. (2017) and Sheikh 
and Wang (2012) which states that the size of the board of directors is positive but not significant effect on capital structure.

\section{The influence of Institutional Ownership on Capital Structure}

Hypothesis test results show the negative effect of institutional ownership but not significant in influencing the capital structure. Negative effect indicates that greater institutional ownership, companies prefer internal financing. The results were not significant on indicating institutional ownership impact on the determination of the capital structure on mining companies listed on the Indonesia Stock Exchange 2012-2016 period. These results are inconsistent with the hypothesis that states greater institutional ownership will lower funding through debt.

Company management with big institutional ownership will be more careful in choosing the funding through debt to finance investments and operations of the company who have a high risk because it can lead institutional investors are sceptical about the company, yet they may take back their investment in the company. It can cause the company to lose funds that would hamper the company's operations, so the company cannot gain profits. The presence of institutional investors can be used as a monitoring tool in order to minimize agency costs incurred by the debt. Thus, the greater the percentage of shares held by institutional investors, it will cause the monitoring becomes more effective since it can control the opportunistic behaviour of managers (Artini $\&$ Diantini, 2014). By increasing institutional ownership, the company will reduce the use of debt.

Not significant results show that institutional ownership of large mining sector does not guarantee to lower their debt, it is because the role of institutional ownership has not been effective in monitoring and controlling the opportunistic behaviour of managers.

This finding is supported by research conducted by Huang and Song (2006), Djabid (2009), Susilawati et al. (2012) and Nanda and Retnani (2017) which states that institutional ownership significant negative effect but not significant on the capital structure.

\section{CONCLUSION AND RECOMMENDATION}

Based on the analysis, it can be concluded only variable profitability and sales growth that affect significant on capital structure, while variable asset structure, firm size, board size and institutional ownership has no significant effect on the capital structure of mining companies listed on the Indonesia Stock Exchange period 20122016.

Some suggestions from the author for is expected the future researcher to add a proxy mechanism of corporate governance and financial performance which is not significant. For the management, the author hopes that they can improve profitability by increasing sales and improving efficiency and effectiveness in order to grow steadily and to reduce reliance on debt without having to lower sales growth.

The writer expects that the investors to choose a company that has high profitability and stable sales growth because it can reduce the risk of bankruptcy of the company.

\section{REFERENCES}

Abor, J., \& Biekpe, N. (2007). Corporate Governance, Ownership Structure and Performance of SMEs in Ghana: Implication for Financing Opportunities. International Journal of Business in Society, 7(3), 288-300.

Alvareza, A., \& Topowijono. (2017). Analisis Pengaruh Ukuran Perusahaan, Profitabilitas dan Pertumbuhan Perusahaan terhadap Struktur Modal. Jurnal Administrasi Bisnis, 50(4), 77-85.

Artini, L. G. S., \& Diantini, N. N. A. (2014). Struktur Kepemilikan Saham terhadap Kebijakan Utang Perusahaan di Bursa Efek Indonesia. Jurnal Keuangan Dan Perbankan, 18(3), 396-408.

Brigham, E. F., \& Houston, J. F. (2006). Fundamental of Financial Management: Dasar-dasar Manajemen Keuangan (10th ed.). Jakarta: Salemba Empat.

Bulan, F., \& Yuyetta, E. N. A. (2014). Pengaruh Corporate Governance terhadap Capital Structure. Diponegoro Journal of Accounting, 3(2), 1-12.

Chen, J. J. (2004). Determinants of Capital Structure of Chinese-listed Companies. Journal of Business Research, 57, 1341-1351.

Darmanto, T., \& Ardiansari, A. (2017). Peran Kebijakan Hutang Memediasi Business Risk dan Firm Size terhadap Nilai Perusahaan. Management Analysis Journal, 6(4), 448-460.

Deesomsak, R., Paudyal, K., \& Pescetto, G. (2004). The Determinants of Capital Structure: Evidence from the Asia Pacific Region. Journal of Multinational Financial Management, 14, 387 405.

Detthamrong, U., Chancharat, N., \& Vithessonthi, C. (2017). Corporate Governance, Capital Structure and Firm Performance: Evidence from Thailand. Research in International Business and Finance, 42, 689-709.

Dewi, D. A. I. Y. M., \& Sudiartha, G. M. (2017). Pengaruh Profitabilitas, Ukuran Perusahaan dan Pertumbuhan Aset terhadap Struktur Modal dan Nilai Perusahaan. E-Jurnal Manajemen Universitas Udayana, 6(4), 2222-2252. 
Djabid, A. W. (2009). Kebijakan Dividen dan Struktur Kepemilikan terhadap Kebijakan Utang: Sebuah Perspektif Agency Theory. Jurnal Keuangan Dan Perbankan, 13(2), 249-259.

Febriana, D., \& Yulianto, A. (2017). Pengujian Pecking Order Theory di Indonesia. Management Analysis Journal, 6(2), 153-165.

Ferdinand, A. (2014). Metode Penelitian Manajemen Pedoman Penelitian untuk Penulisan Skripsi, Tesis dan Disertasi Ilmu Manajemen. Semarang: Undip Press.

Ghozali, I., \& Ratmono, D. (2013). Analisis Multivariat dan Ekonometrika: Teori, Konsep dan Aplikasi dengan EViews 8. Semarang: Badan Penerbit Undip.

Hamzah, M. Z., \& Suparjan, A. (2009). Pengaruh Karakteristik Corporate Governance terhadap Struktur Modal. Media Riset Akuntansi, Auditing dan Informasi, 9(1), 19-33.

Handoo, A., \& Sharma, K. (2014). A Study on Determinants of Capital Structure in India. IIMB Management Review, 26(3), 170-182.

Hardiningsih, P., \& Oktaviani, R. M. (2012). Determinan Kebijakan Hutang (dalam Agency Theory dan Pecking Order Theory). Dinamika Akuntansi, Keuangan dan Perbankan, 1(1), 11-24.

Hartoyo, W. A. K., Khafid, M., \& Agustina, L. (2014). Faktor-faktor yang Mempengaruhi Struktur Modal Perusahaan Tekstil dan Garmen di BEI. Accounting Analysis Journal, 3(2), 247-254.

Haryanto, S. (2016). Profitability Identification of National Banking through credit, Capital, Capital Structure, Efficiency and Risk Level. Jurnal Dinamika Manajemen, 7(1), 11-21.

Horne, J. C. Van, \& Machowicz, J. M. (2005). Prinsippronsip Manajemen Keuangan Edisi Keduabelas. Jakarta: Salemba Empat.

Huang, G., \& Song, F. M. (2006). The Determinants of Capital Structure: Evidence from China. China Economic Review, 17, 14-36.

Indahningrum, R. P., \& Handayani, R. (2009). Pengaruh Kepemilikan Manajerial, Kepemilikan Institusional, Dividen, Pertumbuhan Perusahaan, Free Cash Flow dan Profitabilitas terhadap Kebijakan Hutang Perusahaan. Jurnal Bisnis dan Akuntansi, 11(3), 189-207.

Indrajaya, G., Herlina, \& Setiadi, R. (2011). Pengaruh Struktur Aktiva, Ukuran Perusahaan, Tingkat Pertumbuhan, Profitabilitas dan Risiko Bisnis terhadap Struktur Modal: Studi pada Perusahaan Sektor Pertambangan yang Listing di Bursa Efek Indonesia periode 2004-2007. Jurnal Ilmiah Akuntansi, 2(6), 1-23.

Indriani, A., \& Widyarti, E. T. (2013). Penentu-penentu Struktur Modal Perusahaan yang Sahamnya Masuk Jakarta Islamic Index. Jurnal Dinamika Manajemen, 4(2), 184-191.

Jannah, I. R., \& Khoirudin, M. (2017). Peran Financial Distress Memediasi Kepemilikan Institusional, Kepemilikan Manajerial terhadap Return Saham. Management Analysis Journal, 6(3), 262-273.
Jensen, M. C. (1986). Agency Costs of Free Cash Flow, Corporate Finance and Takeovers. The American Economic Review, 76(2), 323-329.

Kartini, \& Arianto, T. (2008). Struktur Kepemilikan, Profitabilitas, Pertumbuhan Aktiva dan Ukuran Perusahaan terhadap Struktur Modal pada Perusahaan Manufaktur. Jurnal Bisnis dan Keuangan, 12(1), 11-21.

Kasmir. (2015). Analisis Laporan Keuangan. Jakarta: Rajawali Pers.

Kohardinata, C., \& Herdinata, C. (2013). Kepemilikan Manajerial dan Kepemilikan Institusional Terhadap Kebijakan Leverage melalui Pendekatan Kesempatan Bertumbuh dan Risiko Perusahaan. Jurnal Keuangan dan Perbankan, 17(3), 353-361.

Lestari, S. (2015). Determinan Struktur Modal dalam Perspektif Pecking Order Theory dan Agency Theory (Studi Empiris pada Perusahaan Manufaktur yang Listing di BEI Tahun 2010-2013). Jurnal WRA, 3(1), 571-590.

Maftukhah, I. (2013). Effect of Managerial Ownership, Financial Leverage, Profitability, Firm Size and Investment Opportunity Set on Dividend Policy and Firm Value. Jurnal Dinamika Manajemen, 4(11), 69-81.

Maryanti, E. (2016). Analisis Profitabilitas, Pertumbuhan Perusahaan, Pertumbuhan Penjualan dan Struktur Aktiva terhadap Struktur Modal pada Perusahaan Sektor Industri Barang Konsumsi yang terdaftar di Bursa Efek Indonesia (Studi Empiris pada Perusahaan Manufaktur yang Terdaftar di Bursa Efek Indonesia Tahun 20122014). Riset Akuntansi dan Keuangan Indonesia, 1(2), 143-151.

Maytariana, D., Suhadak., \& Kertahadi. (2013). Faktor-faktor Fundamental yang Memengaruhi Struktur Modal Perusahaan. Jurnal Administrasi Bisnis, 2(2), 93-101.

Nanda, D. W., \& Retnani, E. D. (2017). Pengaruh Profitabilitas, Kepemilikan Manajerial, Kepemilikan Institusional dan Resiko Bisnis terhadap Struktur Modal. Jurnal Ilmu dan Riset Akuntansis, 6(3), 945-962.

Naibaho, A., \& Azizah, D. F. (2015). Pengaruh Profitabilitas, Pertumbuhan Penjualan, Struktur Aktiva dan Ukuran Perusahaan terhadap Struktur Modal (Studi Kasus pada Perusahaan Property and Real Estate yang terdaftar di BEI tahun 2011-2013). Jurnal Administrasi Bisnis, 28(1), 131-142.

Nidar, S. R., \& Utomo, R. A. P. (2017). Company Life Cycle and Capital Structure of the Manufacturing Sector in the Consumer Goods Industry. Jurnal Bisnis dan Manajemen, 18(1), 46-54.

Nisak, N. K., \& Ardiansari, A. (2016). Analisis FaktorFaktor yang Mempengaruhi Struktur Modal serta Pengaruhnya terhadap Harga Saham pada Perusahaan-Perusahaan yang tergabung dalam LQ 45 periode tahun 2011-2013. Management Analysis Journal, 5(5), 88-95.

Nisasmara, P. W., \& Musdholifah. (2016). Cash Hold- 
ing, Good Corporate Governance and Firm Value. Jurnal Dinamika Manajemen, 7(2), 117128.

Nugroho, N. C. (2014). Analisis Pengaruh Profitabilitas, Pertumbuhan Penjualan, Ukuran Perusahaan dan Umur Perusahaan terhadap Struktur Modal Usaha Mikro Kecil dan Menengah Kerajinan Kuningan di Kabupaten Pati. Management Analysis Journal, 3(2), 6-10.

Nuswandari, C. (2013). Determinan Struktur Modal dalam Perspektif Pecking Order Theory dan Agency Theory. Dinamika Akuntansi, Keuangan dan Perbankan, 2(1), 92-102.

Pithaloka, N. D. (2009). Pengaruh Faktor-Faktor Intern Perusahaan terhadap Kebijakan Hutang: dengan Pendekatan Pecking Order Theory. Un published Skripsi. Bandar Lampung: Universitas Lampung.

Priambodo, T. J., Topowijono, \& Azizah, D. F. (2014). Pengaruh Struktur Aktiva, Tingkat Pertumbuhan Penjualan, dan Profitabilitas terhadap Struktur Modal (Studi pada Perusahaan Tekstil dan Garmen yang listing di BEI periode 20102012). Jurnal Administrasi Bisnis, 9(1), 1-9.

Rahadian, A., \& Hadiprajitno, P. B. (2014). Pengaruh Good Corporate Governance terhadap Struktur Modal Perusahaan (Studi Empiris pada Perusahaan Manufaktur yang terdaftar di Bursa Efek Indonesia pada Tahun 2010-2012). Diponegoro Journal of Accounting, 3(2), 87-98.

Ridloah, S. (2010). Faktor Penentu Struktur Modal: Studi Empirik pada Perusahaan Multifinansial. Jurnal Dinamika Manajemen, 1(2), 144-153.

Riyanto, B. (2008). Dasar-Dasar Pembelanjaan Perusahaan. Yogyakarta: BPFE UGM.

Riyanto, B. (2011). Dasar-Dasar Pembelanjaan Perusahaan. Yogyakarta: BPFE UGM.

Sahabuddin, Z. A. (2017). Asset Structure Impact on Capital Structure of Capital Market-Listed Firms in Indonesia and Malaysia. Jurnal Keuangan dan Perbankan, 21(3), 376-386.

Seftianne, S., \& Handayani, R. (2011). Faktor-Faktor yang Mempengaruhi Struktur Modal pada Perusahaan Publik Sektor Manufaktur. Jurnal Bisnis dan Akuntansi, 13(1), 39-56.

Serghiescu, L., \& Vaidean, V. L. (2014). Determinant Factors of the Capital Structure of a Firm- an Empirical Analysis. Procedia Economics and Finance, 15, 1447-1457.

Sheikh, N. A., \& Wang, Z. (2012). Effects of Corporate Governance on Capital Structure: Empirical Evidence from Pakistan. The International Journal of Business in Society, 12(5), 629-641.

Supriyanto, D. (2018). Sektor Pertambangan semakin berbobot. Available at: https://m.kontan.co.id/ news/sektor-pertambangan-semakin-bebobot/. 23 Januari 2018.

Suriana, I., \& Saripujiana, D. (2015). Pengaruh Dividen Payout Ratio, Kepemilikan Institusional, Profitabilitas, Struktur Aset dan Firm Size terhadap Keputusan Pendanaan. Jurnal Bisnis dan Kewirausahaan, 11(1), 1-9.

Susilawati, C. D. K., Lidya, A., \& Tin, S. (2012). Faktor-faktor yang Memengaruhi Kebijakan Hutang Perusahaan Manufaktur yang terdaftar di Bursa efek Indonesia. Jurnal Keuangan Dan Perbankan, 16(2), 178-187.

Sutrisno. (2016). Struktur Modal: Faktor Penentu dan Pengaruhnya pada Nilai Perusahaan. Jurnal Siasat Bisnis, 20(1), 79-89.

Thausyah, N. F., \& Suwitho. (2015). Pengaruh Pertumbuhan Penjualan, Struktur Aktiva dan Profitabilitas terhadap Struktur Modal. Jurnal Ilmu Dan Riset Manajemen, 4(9), 1-15.

Wardhani, R. (2015). Risiko Ekspropriasi oleh Pemilik Pengendali dan Tata Kelola Perusahaan terhadap Tingkat Penggunaan Utang Bank. Jurnal Keuangan Dan Perbankan, 19(2), 200-212.

Watung, A. K. S., Saerang, I. S., \& Tasik, H. H. D. (2016). Pengaruh Rasio Likuiditas, Aktivitas, Profitabilitas dan Struktur Aktiva terhadap Struktur Modal Industri Barang Konsumsi di Bursa Efek Indonesia. Jurnal Riset Ekonomi, Manajemen, Bisnis dan Akuntansi, 4(2), 726-737.

Weston, J. F., \& Copeland, E. T. 2008. Manajemen Keuangan Edisi Kesembilan. Jakarta: Binarupa Aksara.

Wikartika, I., \& Fitriyah, Z. (2017). Testing Pecking Order Theory in Jakarta Islamic Index. NeoBis, 11(1), 1-12.

Wirjawan, R. S. (2015). Faktor-faktor yang Memengaruhi Struktur Modal Perusahaan Manufaktur di Bursa Efek Indonesia. Jurnal Bisnis dan Akuntansi, 17(1), 1-19.

Yulianto, A., Kiswanto, Widiyanto, \& Agung, Y. (2014). Linear dan Non-linear Pendekatan dalam Pengujian Manajerial Kepemilikan pada Nilai Perusahaan: Bukti Perusahaan Indonesia. IOSR Jurnal Bisnis dan Manajemen, 16(9), 1-5.

Yulianto, A., Suseno, D. A., \& Widiyanto. (2015). Testing Pecking Order Theory and Tradeoff Theory Models in Public Companies in Indonesia. Handbook on Business Strategy and Social Sciences, 3, 13-18.

Zuliani, S., \& Asyik, N. F. (2014). Pengaruh Profitabilitas, Pertumbuhan Penjualan, Struktur Aktiva dan Tingkat Pertumbuhan terhadap Struktur Modal. Jurnal Ilmu dan Riset Akuntansi, 3(7), 1-16. 